\title{
ABRAHAM IBN EZRA
}

\section{(1092-1167)}

\section{RESEÑA BIOGRÁFICA}

Abraham ben Meir ibn Ezra nació en Tudela, pequeña ciudad del norte de España, cuyo nombre suele ser confundido equivocadamente con Toledo. Residió en Córdoba bastantes años de su juventud, participando de la vida cultural de la academia de Lucena, donde pronto se distinguió como buen poeta.

Escasas son las noticias de la primera etapa de su vida, excepto que permaneció en España y que vivió con serios problemas económicos.

Abandonó la península ibérica - movido por la aventura y huyendo de peligros, según señala sin especificar detalles David Gonzalo Maeso ${ }^{10}$, hacia el año 1139, a los 47 años de edad, y se dirigió al norte de África, al parecer en compañía de su amigo Yehudá Haleví. Se quedó algún tiempo en Egipto, y pasó después a Palestina, Babilonia, Bagdad, y habría llegado a la India. Pero esto último es dudoso, pues, por la cronología aceptada comúnmente, no habría tenido el tiempo necesario.

De hecho, en el año 1140 ya estaba en Roma, entregado a sus trabajos de comentarista escriturario, lo que sin embargo no le impidió recorrer en seis años (hasta 1146), según el dato de sus obras, otras diversas ciudades de Italia, tales como Salerno, Lucca, Mantua y Verona, siempre dedicado a trabajos bíblicos de erudición, como lo demuestra su prolífera obra.

La presentación de ibn Ezra en tierras de Italia, como observara el historiador Graetz, hizo época en la Italia judaica.

¿Qué contraste debia de hacer entre aquellos israelitas el viajero español, con su depurado gusto, su buen sentido y su saber filosófico!"

La mejor recepción la tuvo en Francia, país al que llegó en 1148. Se sabe que allí llevó una vida inquieta y laboriosa, dedicado sobre todo a la redacción de comentarios bíblicos o exégesis. Por sus escritos, además, nos queda claro que también estuvo en otras ciudades francesas: Beziers, Narbona, Burdeos, Angers y Dreux.

11 Id. Ibíd. 
Diez años después, a la edad de 66 años, se encaminó a Londres, lugar en el que prosiguió sus actividades, componiendo y traduciendo diversas obras, trabajos que le sirvieron de lenitivo frente a la muerte de su hijo Ishaq, y a la habitual falta de recursos que le acompañó.

Nada se sabe de Abraham ibn Ezra desde 1167, que se encontraba en Calahorra, ciudad al norte de España al igual y muy cercana a la ciudad natal. En esos momentos terminaba una recensión de su comentario al Pentateuco.

\section{MAPABIOGRÁFICO*}

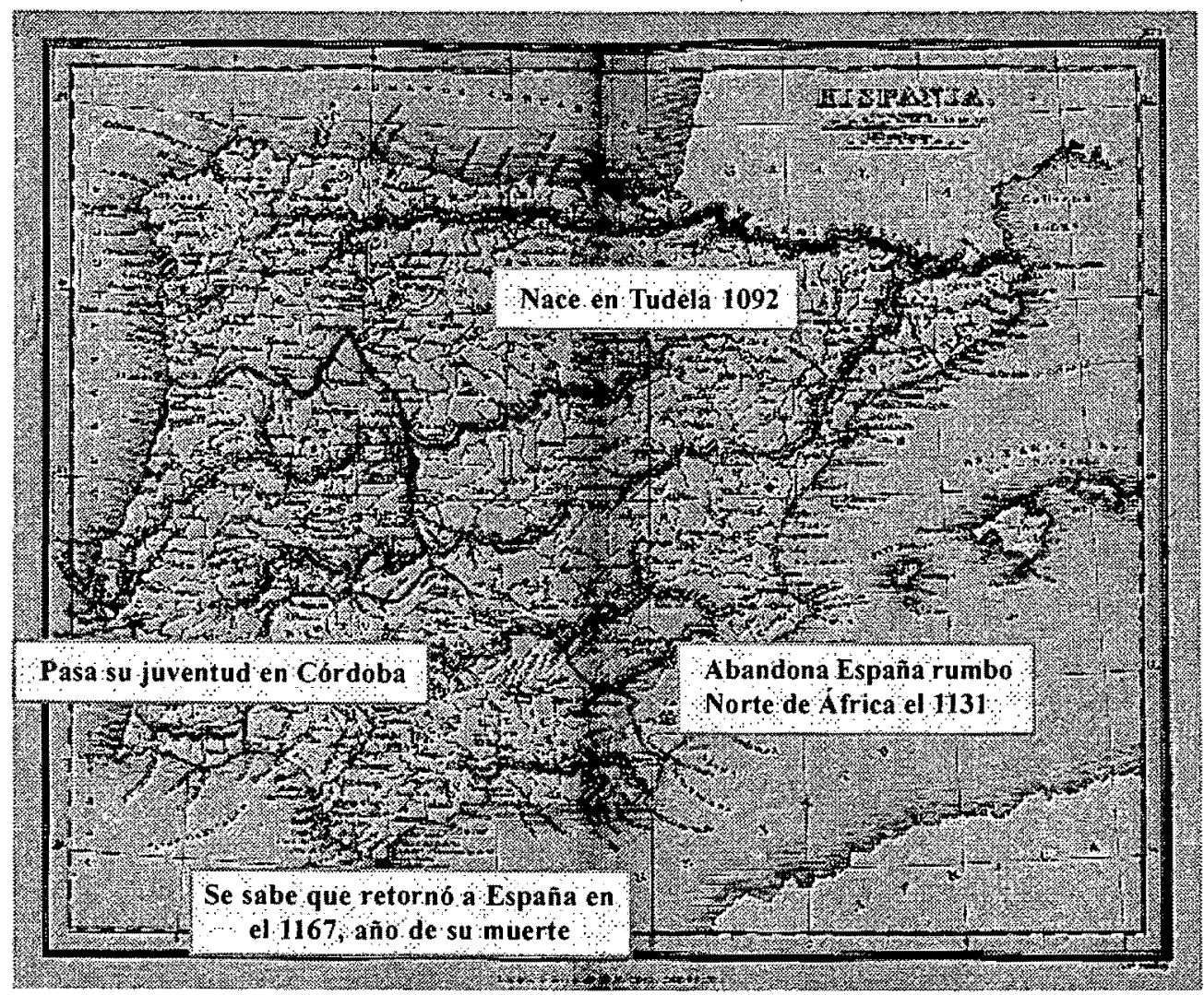

- El mapa utilizado fue extraido de Internet: From A Classical Atlas of Ancient Geography by Alexander G. Findlay. New York: Hatper and Brothers 1849 (sitio Internet: 209.15.138.224/inmonacional/ n_hispania $1849 . \mathrm{htm}$ ) 


\section{TEMPLE}

Abraham ibn Ezra fue un escritor hispano-hebreo que, tanto en su vida como en sus escritos, representaba un personaje versátil, incansable y peculiar.

Viajero infatigable, recorrió los principales países y las ciudades más importantes de las tres partes del mundo medieval, y que en un ambiente de constante desplazamiento, con todas sus consecuencias y las carencias económicas que le acompañaban, estudió y escribió abundante y relevantemente.

Cultivó la poesía sagrada y la profana, descollando especialmente en el género epigramático; fue reputado astrólogo y astrónomo, matemático, filósofo y teólogo, talmudista y cabalista. Compuso diversas obras gramaticales, mantuvo asidua correspondencia epistolar, tradujo diversas obras del árabe al hebreo, pero, sobre todo, se destacó por sus comentarios exegéticos a casi todos los libros del Antiguo Testamento, que tanta fama le granjearon entre sus correligionarios. Su erudición fue famosa.

\section{OBRAS}

POÉ TICA: El cultivo de la poesía fue para Abraham ibn Ezra un ejercicio especialmente desarrollado en la juventud y bastante más eventual en el resto de sus años, dedicados más intensamente al estudio prolijo de la Biblia y la gramática como detallaremos más adelante. Sin embargo, son bastante las composiciones que nos ha legado, unas profanas, en mayor número, y otras sagradas. A través de su poesía sagrada se descubren sus mejores dotes literarias: la fuerza, el fervor y la delicadeza matizan sus composiciones.

Sus ideas filosóficas y cosmológicas se descubren en sus poesías hímnicas, en las cuales canta la gloria de Dios, su alteza y su inaccesibilidad, su reino sobre todos los seres, desde los coros de los ángeles, esferas celestes, planetas que discurren en sus órbitas, hasta los planetas más humildes; el entusiasmo del Salmista repercute en él al considerar la naturaleza como una obra maravillosa de Dios.

Más importancia que sus poesías laudatorias tienen las penitenciales y suplicatorias, y todavía mayor interés despiertan su poesias de destierro. Conmovedora es la qiná o elegía sobre la ruina de las aljamas españolas y magrebíes, causada por la devastación almohade.

Asimismo variadas son las geulot y ahabot de tipo epitalámico del Cantar de los Cantares, qinot y zulot en forma dialogada, en todas las cuales es cantada en forma muy bella y consoladora la esperanza mesiánica, la tradición nacional judaica.

Su gran dominio de la técnica y el lenguaje lo hicieron triunfar sobre las dificultades que su criticismo racionalista hubo de poner a la libre expansión de sus cualidades poéticas ${ }^{12}$. 
GRAMÁTICA: Su primera obra gramatical, compuesta en Roma, fue titulada Moznayim (Balanza) o Mozné ha-Lašon (Balanza del idioma), que contiene una explicación de la terminología gramatical; pero más que un simple vocabulario viene a ser una gramática en forma abreviada.

En Mantua compuso un nuevo tratado gramatical, Zukot ha-lašon (Pureza de la Lengua, primera edición, 1546), obra de mayor empeño que la anterior y de más amplio marco. Además de la doctrina gramatical, contiene varios capitulos sobre prosodia y teoría de la métrica.

Sefat yéter (La Lengua Perfecta), escrita en Lucca, es una defensa de Saadya contra las críticas de Dunás ben Labrat, pero contiene además puntos de vista propios. Se publicó en 1838 y 1843.

$Y^{e}$ sode Diqdud o Séfer ha-Y'sod (Fundamentos de Gramática o Libro del Fundamento), obra aún inédita, es una gramática completa.

Su postrer obra gramatical fue la titulada Safa brura (El Lenguaje puro, primera edición 1830 ), en la cual se discuten ciertos problemas gramaticales, aunque en forma algo confusa. En la introducción se ocupa de algunos aspectos de la exégesis bíblica y, asimismo, de las relaciones del hebreo con el árabe y el arameo.

También escribió otras dos obras acerca de las letras hebreas: Sod ha-t'munat ha-otiyot (Secreto de la forma de las letras), en que trata de éstas cabalísticamente, y Hida al otiyot (Enigma de las Letras), las cuatro quiescentes, traducida al latín por Cohén de Lara.

La contribución de ibn Ezra a la filología hebraica estriba más que en la originalidad de sus teorías en el hecho de que las primeras obras gramaticales sistematizadas, escritas en hebreo fueron las suyas, y en ellas abarcó el fruto de los trabajos llevados a cabo por los grandes gramáticos y lexicográficos españoles. Así hizo accesible este cúmulo de conocimientos a los judios de la Europa Occidental que no entendían el árabe. Sin embargo, Ibn Ezra no fue un mero compilador, sino que en todo estaba su conocimiento ${ }^{13}$,

FILOSÓFICA: Séfer ha-šem (Libro del Nombre, es decir, de Dios), es una exposición de teorías acerca del concepto de Dios, partiendo de algunos de sus nombres; $Y^{\prime}$ sod mora (Fundamento de la Reverencia, es decir, del conocimiento de Dios), completa desde otros puntos de vista el tema del anterior. Sobre la existencia de Dios y sus atributos versa el Arugat ha-Jokmá u-pardes ha-mezimma (Ramillete de Sabiduria y Pensil del Pensamiento).

Śa'ar ha-šamáyim (La Puerta de los Cielos) es una introducción al Génesis, de la que solamente se ha conservado el primer capitulo.

Aparte de estas obras, la filosofía de Ibn Ezra está diseminada en otras muchas otras, incluyendo las ya nombradas poéticas. 
De materias estrictamente filosóficas son Bèt middòt (Casa de las costumbres), de ética, y Séfer Hiqqayon (Libro de Lógica).

COMENTARIOS BÍBLICOS: Esta parte de su obra total fue escrita fuera de España. Representa la cumbre de la exégesis hispano-hebrea y es un resumen de la misma, escrita especialmente en árabe; pero también en esto fue más que transmisor. Después de Raší fue el comentador más estimado. Sus comentarios se extienden a casi todos los libros del Antiguo Testamento.

Séfer sodót ha-Torá (Libro de los secretos de la Ley), se encuentra manuscrito en la Biblioteca Vaticana y también en la de Leyden. Asimismo, sabemos que realizó otros comentarios a diversos libros de la Biblia.

Finalmente, escribió textos sobre estudios matemáticos, obras de astrología y astronomía.

ASTRONOMÍA Y ASTROLOGÍA: Estas materias están estrechamente ligadas en la Edad Media y, junto a sus comentarios biblicos, fueron las que mayor fama le otorgaron.

Al primer grupo pertenecen: Keli ha-nehošet (Instrumento de cobre), sobre el astrolabio, y la traducción al hebreo (Londres, 1160) del comentario del astrónomo oriental Ahmad ben al-Mutanna ben Abd-al-Karim a las tablas de $A l$-Juarizmi (el original árabe no se conserva).

Al grupo de astrologia corresponden: Séfer ha-noldót (Libro del nacimiento), Séfer haqoralót (Libro del destino), que contiene, lo mismo que el anterior, reglas para adivinar la suerte y sino de cada uno, según el curso de los astros, y Séfer istaqninut (Libro de Astrologia). También, vale mencionar un calendario hebreo inserto en el Majzor español de Venecia (1656) y el Séfer hamorot (Libro de las Luces), sobre los días críticos. 


\section{PRESENTACIÓN DEL CORPUS DE TRABAJO}

\section{Justificación}

La selección y compilación solo de textos poéticos como corpus de trabajo responde, en primer orden, a que si bien Abraham ibn Ezra escribió obras narrativas y estudios sobre diversos temas filológicos, estas fuentes no han llegado a nosotros. De hecho, hemos heredado en general poco material de toda su producción. Sabemos que algunos de sus escritos están en centros especializados recopilados por una cadena de escritores a través del tiempo $y$ de otros que se encuentran en la biblioteca del Vaticano ${ }^{14}$.

Segundo, nuestra búsqueda abarcó todas aquellas fuentes accesibles en Santiago de Chile, que, incluyendo seis versiones encontradas en inglés, y traducidas aquí al español, nos dio suficiente material, consistente en 19 textos poéticos hispano-hebreos.

Asimismo, el presente trabajo de compilación pretende mostrar, mediante textos literarios, rasgos trascendentes y representativos de la cultura hispano-hebrea que permitan darla a conocer y rescatarla del tiempo y proporcionar un vasto material de estudio que podría ser útil en futuras investigaciones, o para quien desee tener antecedentes literarios de la época en España.

Las fuentes utilizadas para la presente compilación fueron las siguientes obras:

J.M. MILLÁS VALLICROSA, La Poesía Hebraica Postbiblica. Editor José Janés. Barcelona, España, 1953;

J.M. MILLÁS VALLICROSA, La Poesia Sagrada Hebraicoespañola. Madrid, España, 1940.

Editada por el Consejo Superior de Investigaciones cientificas. Patronato M. Menéndez Pelayo. Instituto Arias Montano. Escuela de Estudios Hebraicos; y

David GOLDSTEIN, Hebrew Poems from Spain. Introduction, Translation and Notes

\section{Nómina total de textos Clasificados POR REcopilador}

José María MILLAS VALLICROSA, en La Poesia Sagrada Hebraicoespañola:

1) BAQQA ŠS, registro $N^{\circ} 103$.

2) SELIHA, registro $N^{\circ} 105$.

3) ZULAT, registro $N^{\circ} 109$. 
José María MILlAS VALliCROSA, en La Poesía Hebraica Postbiblica:

4) el No $175, \mathrm{pp} .217$.

5) el No 176, pp. 217 (corresponde a Luckless de la recopilación de David Goldstein. Observar las diferentes versiones o traducciones del mismo poema).

6) QINA, No177,pp. 218.

7) REŠUT, No 178, pp. 220. (recopilado antes por Vallicrosa, bajo igual traducción, en La Poesia Sagrada Hebraicoespañola).

8) SELIHA, 179, pp. 220-221.

9) PLEGARIA POR LA LLUVIA, 180, pp. 221 (recopilado también en La Poesia Sagrada Hebraicoespañola, de J. M. MILLÁS VALLICROSA, bajo el titulo de Oración por la lluvia, pero la trascripción del poema es la misma en ambos libros).

10) MEORA, 181, pp. 222-223.

11) GUEULA, 182, pp. 224-225.

12) SELIHA, 183, pp. 225.

13) AHABA, 184, pp. 226-227.

David GOLDSTEIN, en Hebrew Poems from Spain:

14) Luckless

15) I have a garment

16) God supreme

17) All glory to his name

18) How is it you have not given this thought?

19) On the death of his son, Isaac

\section{REPRODUCCIÓN DE LOS TEXTOS}

BAQQAŠA -103

En verdad, Dios verdadero Tú eres, aunque yo no te vea, pero en la magnitud de tus bondades, siempre te veo.

Antes que te conociera, tus mercedes me habias prodigado, hasta el presente me has recordado mientras que yo ¡cuántas veces te he olvidado! 
Tu voluntad ha sido favorecerme sin que necesitaras recompensa; muy excelso es tu nombre, pero próximo yo te he encontrado.

Mis delicias están en tu ley, como las del esposo en la esposa; como Dios de mi vida te invoco, cuántas veces te he invocado.

\section{SELIHA - 105}

Me postraré rostro en la tierra, pues no hay cosa más baja que ella. Me humillaré a la faz del Altísimo, el Excelso sobre toda excelsitud. ¿Cómo me congraciaré con Él? ¿Con mi espíritu? ¿Acaso no viene de Él? ¿Con lo más escogido de mi cuerpo? Él lo vivifica y no hay nada más noble que el alma. No hay linde ni extremo para su grandeza. ¿Cómo mi lengua lo ilustraría? Inaccesible más que los altos cielos, y próximo más que mi carne y mis huesos. He aquí que vengo a ti, Dios mío, pues no hay ayudador fuera de ti. ¿Acaso las cohortes de los cielos y la tierra no fueron creadas como yo mismo? ¿Cómo esperaría la salvación de parte de ellas? Mentira es auxilio de las criaturas. Ciertamente el siervo no puede refugiarse sino en aquel que lo adquirió.

¿Qué más pretenderia yo conocer, sabiendo que para mi bien me has creado?

Tus misericordias rebasan todo término, y mis pecados superan a las arenas del mar. ¿Cómo levantaré mi mirada hasta ti? si también ella ha pecado.

¿Y qué responderán mis labios? si también ellos hanse depravado.

La vanidad de mi corazón ha acarreado a mi alma lo que mi enemigo hacer no podia. Por ello una conmoción me ha sobresaltado. iAy de mí, pues me he rebelado! Mi mala inclinación me ha descarriado, pues no era mi voluntad hacerte agravio. Mis maldades a mí solo han afectado, pues Tú sólo me dispensas benignidades. Muéstrame el camino de mi salud pues todo lo que yo sé, Tú me lo has enseñado. Las palabras de mi corazón hice sentir a mi oído ;Óyelas Tú, desde los cielos!

SELIHA -179

Mis manos extenderé - y mis lágrimas derramaré, por la magnitud de mis faltas - y la magnitud de mis culpas. ¡Oh Dios!, endereza mis actos - y alivia mis pecados.

¡Roca mía!, socórreme - hasta el momento en que juzgues.

"En mi clamar a ti respóndeme - ioh Dios de mi justicia!"

Con endechas y gemidos - el perdón te suplico, con la suavidad de los salmos - en la asamblea de los elegidos, con cánticos esmerados - y con lo selecto de mis obras. Te ensalzaré, - tu nombre confesaré, 
y te amaré - joh Señor, fortaleza mía!

"En mi clamar a ti, respóndeme - joh Dios de mi justicia!"

Tú que cabalgas sobre las auroras - e inquieres las conciencias, $y$ acoges las contriciones - a modo de pingües sacrificios,

Tú que contienes los corazones, - devuelve tus millares a la ciudad de mi complacencia. - ¡Roca mía y cobijo mío, mi herencia y mi suerte, - Tú, don de la posesión mía! "En mi clamar a ti, respóndeme - joh Dios de mi justicia!"

He aquí que en ti esperaré,- fuente de vida y refrigerio, tu fuerza declararé - y a ti adoraré; tu salud otórgame,- a mí socórreme, para ampararme,- cobijarme y proporcionarme - el pan de la ley mía.

"En mi clamar a ti, respóndeme - joh Dios de mi justicia!"

Excelso rey mío,- en ti está mi apoyo, acoge el canto que te dedico, - y al pobre así congratula:

-No temas, - pues contigo estoy, te corroboraré, te auxiliaré y te asiré con la diestra de mi justicia. "En mi clamar a ti, respóndeme - joh Dios de mi justicia!"

\section{SELIHA -183}

¡Oh Dios!, tus larguezas prestamente me visiten, a tu gracia convierte mi corazón y acógeme, sobre tus senderos endereza mis pasos. $\mathrm{y}$ asi no vacilen mis vías. Tu ley enséñame. Séasme alcázar de fortaleza en el día de la aflicción, y quiebra el brazo que se alzó para prenderme; no te acuerdes ya más de los pecados de mis mocedades, y para su recuento no escudrines mi faz en el día de mi juicio.

Tiéndeme tu mano para que no olvide tu ley, acelera el término de la redención y rescátame. Así contemple, cuando reintegres a Sión nuestras congregaciones, el día en el cual restaures tu Templo y nos reedifiques, y digas a la hija de Sión: - "Yo vindicaré tu sangre de parte de tus adversarios, y mis ovejas apacentaré". 
(Israel):

Diré al aquilón - mi vigor y mis fuerza -.

Al austro: Permite a mi hijo - que more en mis cámaras -.

¡Diestra de Dios!, edifica - mi casa y mis moradas,

para que suba y entre en la ciudad - el humilde, montado sobre

pollino,

mientras que yo en medio del santuario - con citara y cánticos

vendré, para ofrecer mi adoración.

Llegaron los días de regocijo - antes que se cumplieran los días del mundo, los dolores se desvanecieron - con todas sus pesadillas,

pues las moradas de su tienda - Él construirá junto a sus ruinas.

¡El amado!, cuyas palabras son como la miel - y como el maná su

acento,

ilustre y magnifico es su nombre - pues Él obrará maravillas, por obra de Elías de Tisbe y el Mesías de Belén.

(Dios):

¡Oh esposa!, sal del cautiverio - con omato y diadema, como en los dias juveniles permanece,- llena de honor y atavíos, como gacela, a la tierra prometida - vuelve después que fuiste dispersada.

(Israel):

Grande será la gloria postrera - y menguado será el que rompa la ley, Aquel que alargó la aflicción - tomará la lanza en su mano y yo mi oración. ¡Cobijo mio!, el dolor de mi llaga - alivia, y torne la salud, aparta la violencia de mis opresores, - da prosperidad a mis amadores, ya que varios plazos, y aún - medio plazo, la Redención he esperado; a quien invoca tu nombre responde, - el rebaño que vendiste rescata, el muro que demoliste reedifica, - la mansión que desechaste habita, y acelera mi salvación.

QINA - 177

(Por la ruina de las comunidades judias de España causada por los almohades)

¡Ay! sobre Sefarad descendió una calamidad desde los cielos; mis ojos, mis ojos vierten lacrimosas aguas.

El llanto de mis ojos, como llanto de avestruz, es por la ciudad de Lucena; 
libre de tachas, aparte allí moró la cautiva comunidad, sin cesar hasta cumplir la fecha de mil setenta años; pero vino su día, huyó su gente y ella quedó como viuda, huérfana de ley, sin Escritura, sellada la Mišná, el Talmud estéril se tornó y todo su esplendor perdió, sicarios y hombres de violencia recorren acá y acullá, el lugar de la oración y de la loanza en casa de orgía se convirtió.

Por eso lloro y se crispan mis manos y en mi boca hay siempre un lamento y no tengo reposo diciendo: - ;Oh si mi cabeza se tornara aguas!

¡Ay! Sobre Sefarad descendió una calamidad desde los cielos; mis ojos, mis ojos vierten lacrimosas aguas.

Mi cabeza decalvaré y amargamente gemiré por la comunidad de Sevilla, por sus principes que han sido vulnerados y por sus hijos hoy cautivados, por sus hijas, delicadas, hoy entregadas a una religión extraña.

¿Cómo ha sido abandonada la ciudad de Córdoba y convertida en mar de ruinas?

Sus sabios y personajes eminentes murieron de sed y de hambre; ningún judío, ni uno solo, quedó en Jaén ni en Almería, ni en Mallorca ni en Málaga quedó refrigerio alguno, los judios que habian huido fueron cruelmente heridos. Por esto me lamentaré muy amargamente, muy mucho me plañiré, $\mathrm{y}$ mis gemidos por causa de mis dolores fluirán como aguas.

¡Ay! sobre Sefarad descendió una calamidad desde los cielos; mis ojos, mis ojos vierten lacrimosas aguas.

¡Ay! Clamaré, como mujer en dolores, a causa de las aljamas de Sigilmesa, ¡la ciudad de los gaones y de los sabios! La tiniebla ha cubierto su luminar, ha sucumbido la columna del Talmud y el edificio hase derruido, la Miśná, en oprobio, con los pies han pisoteado; a causa de los hombres ilustres, alanceados, pues el ojo enemigo no perdonó.

|Ay! Cómo expiró la aljama de Fez en el día en que fue librada al saqueo, ya no hay fuerza en el calle de Tlemecen y su gloria marchitóse. Mi voz levantaré con amargura, a causa de Ceuta y de Mequínez

y la túnica rasgaré a causa de Dara, que ya antes fue asolada; en día de sábado, el joven con la doncella su sangre derramaron como aguas. 
¡Ay! Sobre Sefarad descendió una calamidad desde los cielos; mis ojos, mis ojos vierten lacrimosas aguas.

Pero, ¿qué responderé, si a causa de mis pecados esto ha sucedido, y de parte de mi Dios, mi cumbre roquera, el mal contra mí se ha decidido? ¿En quién esperaré y qué cosa invocaré si todo es obra de mi mano?

Arde mi corazón dentro de mis entrañas, a causa de mi alma, pues ha pecado, y desde tierra, el puerto de su alegría, a tierra inmunda ha sido desterrada. Avergonzada y muda no acierta a contar sus desventuras, mas con el dolor de su corazón en las misericordias de su Roca espera,

a fin que del exilio decrete redención, pues en la sombra de sus alas se ampara, y si su nombre recuerda, desde la cárcel en que se halla, entonces revive.

Pero su llanto sobre sus mejillas, a la vera de la sirvienta, mucho ostentará hasta que se aparezca el Señor desde los cielos.

\section{REŠUT -178}

En la Ley de Dios me aplicaré toda mi vida esperando que el Señor me conceda su galardón; en su huerto de delicias mi voluntad se deleitará y en los dias de mi aridez la Ley mi rico venero será. ¡Señor!, con los ojos del corazón te he visto, $y$ aun en tu Ley, ilustre en fortaleza, enséñame a practicar el recto camino; te magnificaré y Tú magnificarás mi gloria.

Los cielos y las alturas no alcanzan a soportar tu grandeza, jcuánto menos lo podrá mi palabra! Cobijarse en ti ansía siempre mi alma, y en la adoración de tu nombre puse mi honor.

\section{PLEGARIA U ORACIÓN POR LA LLUVIA}

Dios se dispone desde su excelso estrado a compadecerse de la tierra. ¿Quién sino Él se compadecería? Él pronuncia su palabra y sus bendiciones, y la lluvia torrencial viene a su tiempo.

Ciertamente tu nombre glorioso está encumbrado sobre toda cosa, y el pueblo que habita la baja tierra la liuvia apetece; Tú, entonces, das tus órdenes a las nubes, 
y la tierra produce su grano y su mosto,

y el árbol del campo da su fruto a su tiempo.

Los cansados y los deprimidos se corroboran merced a su palabra, pues Él da orden a las nubes para que viertan sus aguas,

y Él proporciona a cada uno su sustento.

¡Abra el Señor para ti su tesoro, y descienda la lluvia sobre la tierra a su tiempo!

\section{MEORA - 181}

Al Dios magnífico y ensalzado clamaré desde mi tristeza y langor, hasta que restaure el casal de mi gloria, y retorne mi Rey y mi salvador.

Espero, oh piadoso, en tu gracia, pues fuera de ti no tengo otro amparo; desde la altura contempla mi pena, cómo, todos los días, tu siervo es probado.

Mientras mi pecado pongas ante ti, hasta llegar el día del juicio y de la obra, sé propicio al pueblo mustio y caído; oh mi Rey, mi refugio y mi asilo, no me retribuyas según mis méritos para que mi pueblo no sea cortado alrededor.

Al Dios magnífico y ensalzado clamaré desde mi tristeza y langor, hasta que restaure el casal de mi gloria, y retorne mi Rey y mi salvador.

Oh Piadoso, hacedor de toda cosa, recuerda el pacto con tus fieles, ¿hasta cuándo el enemigo profanará tu nombre a mi faz? No puedo chistar ante él, por miedo de inducir a mis exactores, heme quedado desnudo y saqueado, disperso en el albergue de mis peregrinaciones; por ellos soy tenido como impura abominación, después que se exhalaron mi mirra y mi olor. 
Al Dios magnifico y ensalzado clamaré desde mi tristeza y langor, hasta que restaure el casal de mi gloria, y retorne mi Rey y mi Salvador.
¿Acaso quitará el Señor
la afrenta de su pueblo electo;
acaso Él alboreará en las alturas
para agraciar a su primogénito,
y se aprestará a redimir a Israel
y a instaurarlo en su esplendor?
Entonces el doncel y el canoso se alegrarán cuando Tú convoques el año de liberación, y en mi solar la caña balsámica vuelva, con el rescate, a dar su flor.
A] Dios magnífico y ensalzado clamaré desde mi tristeza y langor, hasta que restaure el casal de mi gloria, y retorne mi Rey y Salvador.

Oh Altísimo, tu faz imploran cada día los que sobrellevan su carga. ¿Hasta cuándo esperarán el término de las proféticas consolaciones? ¿Cuândo saldrán redimidos al cumplirse el prodigio y la señal? Alabaremos tu nombre, profanado, y Tú te reintegrarás a tu santuario, cuando allí torne la noble hija del Rey y marchen los pueblos a su resplandor.
Al Dios magnífico y ensalzado clamaré desde mi tristeza y langor, hasta que restaure el casal de mi gloria, y retome mi Rey y mi Salvador,

GUEULA -182

\section{(Dios:)}

¡Afligida mia! hasta ahora estabas desolada, pero levántate, sube, pues has sido perdonada,

"Cuán bella eres, cuán agraciada!" 
Hija de mis entrañas, en tu faz reside

la vida, de tu boca la miel destila,

la belleza y la gracia son tus hechizos,

pendientes pusiste en tus orejas,

y tu mirada con antimonio es hermoseada, sube en medio de la noche

"Cuán bella eres, cuán agraciada!"

Elegida mia entre las hermosas,

levántate sube en medio de la noche

y sal entre las danzas y los coros,

tus pecho florezcan como racimos;

aunque culpable de infidelidades fuiste considerada.

"¡Cuán bella eres, cuán agraciada!"

¡Cómo te has marchitado!

Tú la hermosa entre las mujeres,

que como la aurora te presentabas,

he aquí que en oprobio te han colocado;

pero sì has caído, en verdad serás levantada.

“¡Cuán bella eres, cuán agraciada!”

¿Por quế suspiras, hija mía?

Levántate y sal conmigo,

te conduciré a la casa de mi gloria.

Yo seré tu esposo y tú serás mi esposa

y para siempre serás consolada.

"Cuán bella eres, cuán agraciada!"

\author{
AHABA -184 \\ (Israel:) \\ ¿Dónde está tu poder, oh diestra de Dios? \\ con mi propio sentido te he escuchado; \\ pero mi alma no se atreve a levantarse, \\ como si ella no te hubiera considerado. \\ En mí arde un fuego de celos \\ por la reina que está prisionera, \\ siendo el ludibrio y la irrisión de todos, \\ a viudez, de por vida, condenada. \\ Descansan pacíficos mis adversarios
}


mientras yo voy desterrada y errante, la mano de todo hombre impuro es sobre mi, y me dice: -En santidad te sobrepujo, pues, ¿qué esperas, siendo así que pasaron las generaciones y yo te he heredado?

¿Dónde está tu poder, oh diestra de Dios?

Con mi propio sentido te he escuchado; pero mi alma no se atreve a levantarse, como si ella no te hubiera considerado.

Demasiado he morado en obscuridad contando el dolor de mi infortunio, pero, ¿cómo podré esperar refrigerio, si mi Dios no está dentro de mí? Lloraré en los senos de mi alma, ¿Cómo daría lenitivo a mi corazón?

(Dios:)

Interroga, oh ciudad de Ariel, interroga si es que te he olvidado.

Ciertamente lágrimas a raudales vierten mis ojos, puesto que huérfana de gloria te he dejado.

¿Dónde está tu poder, oh diestra de Dios?

Con mi propio sentido te he escuchado; pero mi alma no se atreve a levantarse, como si ella no te hubiera considerado.

(Israel:)

Con las visiones de los videntes convocados el fin de mi destierro no he hallado, he escudriñado todos mis profetas, y en el arcano de mi redención no he dado, pero si mis pecados me han acongojado una voz que oi me ha alegrado, todos los profetas hablaron a mi ascendencia: ¿Cómo te habria yo abandonado? ¿Por la gracia de tus días juveniles con amores eternos te he amado!

¿Dónde está tu poder, oh diestra de Dios?

Con mi propio sentido te he escuchado; pero mi alma no se atreve a levantarse, como si ella no te hubiera considerado. 
He aquí que la faz del orbe se ha renovado y como de túnicas de regocijo se ha revestido en el día en el que el joven se goza de su amada, pues es precepto de Dios que la mujer sea para el hombre.

En verdad él se ha llevado lo que ansiaba y ella también encontró lo que apetecía y buscaba. Sólo para él era digna una muchacha como ésta, la cual había sido votada a él desde su mocedades. Si hubiese solicitado pertenecer a otro, ciertamente el orbe se hubiera conmovido.

$N^{\circ} 176$

La esfera y los signos zodiacales se desviaron en sus órbitas, al momento de mi natividad; si la mercancía objeto de mi comercio fueran lámparas, el sol no se habría ocultado hasta el momento de mi muerte; aunque me esfuerzo por prosperar, no tengo éxito alguno, pues pervierten mi suerte las estrellas de mi cielo; si fuera mercader de sábanas, no moriria nadie durante mis dias.

\section{POEMAS TRADUCIDOS DEL INGLÉS AL CASTELLANO}

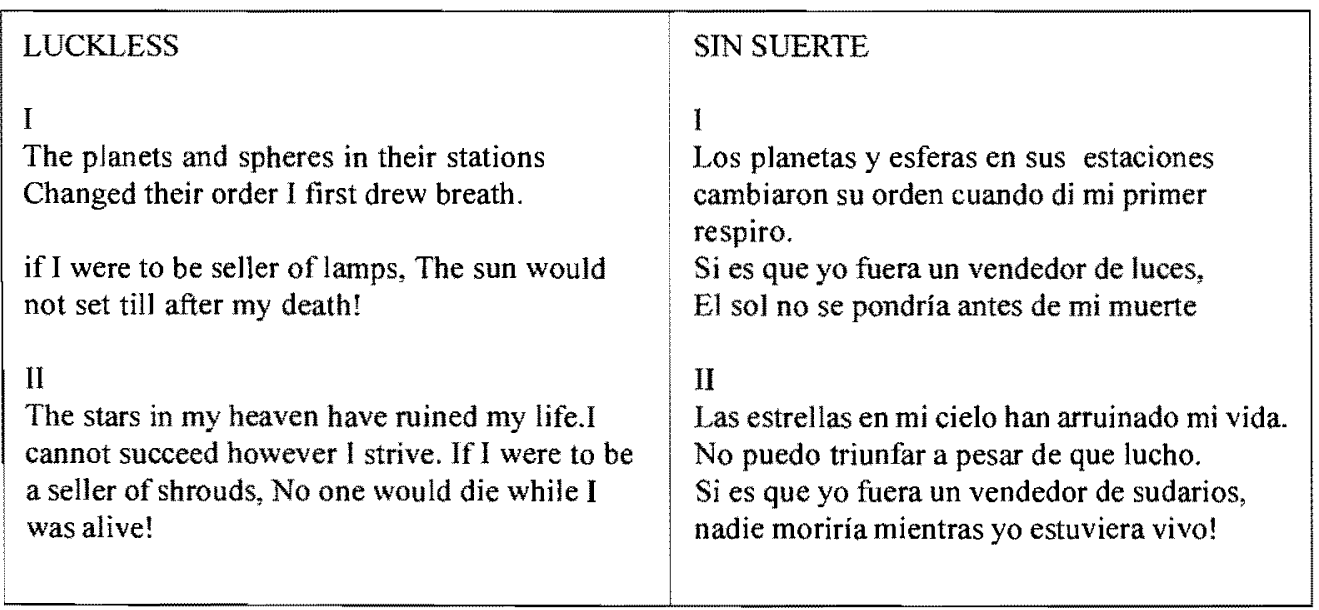




\section{HAVE A GARMENT}

I have a garment. It is like a sieve

With which to sift barley and wheat.

At the death of night I spread it out like a tent And the stars of heaven put through it their light. From within it I see the moon and the Pleiades, And, when it is bright, there peeps through Orion.

I get tired from counting all its holes

Which seem like the teeth of a saw in profusion.

A piece of thread, to sew up its rags, Both warp and woof, would be superfluous.

If a fly landed on it with all his weight,

He, like an idiot, would soon grumble and curse.

My God, make good the repairs which it needs.

Make a mantle of praise from these tattered weeds.

\section{TENGO UNA PRENDA}

Tengo una prenda. Es como un cedazo con el cual espolvorear cebada y trigo.

Al caer la noche lo despliego como una tienda y las estrellas del cielo lo traspasan con su luz. Desde su interior veo la luna y las Pléyadas, $\mathrm{y}$, cuando brilla, guiña Orión a su través.

Me canso de contar todos sus agujeros que parecen como dientes profusos de una sierra. Un trozo de hilo para coser sus harapos, y ambos, urdimbre y tejido, serían superfluos, si una mosca aterrara sobre él, con todo su peso, él, como un idiota, rápidamente rezongaría y maldeciría.

Oh, mi Dios, cuida las costuras que necesita. Haz un manto de alabanza de estas andrajosas malas hierbas.

\section{SUPREMO DIOS}

Dios excelso en majestad, alabada sea tu gloria.

El creador de toda forma que hayamos visto o desconozcamos. La base de los pensamientos fue establecida con su nombre: ¿Quién a él puede entender?

Aquellos que ven el bien que hace los senderos por los cuales él va, ¿pueden negar su excelencia? Todo lo que él ha hecho nacer vive para testificar su dignidad.

Quien perciba su poderio, por sus propios ojos o pensamiento, o a través de la mirada interior de los profetas, lo confesará a lo largo de su vida. porque en su mano su alma está segura. 


\section{ALL GLORY TO HIS NAME}

To him who delights in music and rhyme, I proclaim:

"All glory to his name".

I consider. His work is good.

I sing to him who has numbered the world, And created man from an earthen clod,

Pure,

Like a king in his tower.

He exists in all. From his hand comes all. Nothing approximates him to the full. Compared with him, all is null.

What shall I say? The world entire is poor. His knowledge is far from man's power.

His might and the mystery of his skies are far.

Around his throne are his servants of fire. His awe extends through the hosts of the air. He has built his home on the waters above. he moved his lips. The havens were clothed. There are wonderful things in all his work. Creation bears witness for his glory's sake. To the prophets he revealed all that was dark. The soul that appears to him to be dear He will steer in the pathway of those that fear.
TODA LA GLORIA PARA SU NOMBRE

Para quien se deleita en música y rima, proclamo:

"Toda la gloria para su nombre"

Considero. Su obra es buena.

Canto a quien ha numerado el mundo, y creado al hombre de un terrón de barro, $Y$ ha puesto alma en su más intimo núcleo, Puro, como un rey en su torre.

El existe en todo. De su mano viene todo. Nada se le compara en plenitud.

Comparado con él, todo es nada.

¿Qué podré decir? El mundo entero es pobre.

Su conocimiento está lejos del poder del hombre.

Su poder y el misterio de sus cielos son remotos.

Alrededor de su trono están sus sirvientes de fuego. Su terror cae sobre las huestes del aire. Ha construido su hogar sobre las aguas. Movió sus labios: los cielos se vistieron. Hay maravillas en toda su obra. La creación testifica a favor de su gloria. A los profetas reveló todo lo que era oscuro. El alma que aparece ante él como querida la guiará por el sendero de aquellos que temen.

\section{HOW IS IT YOU HAVE NOT GIVEN THIS THOUGHT?}

If, my soul, you do not know your end, See a hint and a sign in your beginning. Your foundation is nil, your building on the void, Your entrance like your exit, your life your ending.

Then why do you rest, and make vanity your nourishment?

Turn, for you are moving like a nomad's tent.

You will not be found when you are sought.

How is it you have not given this thought?

You have clung to your desire, which is really your foe.
¿COMO ES QUE NO TE HAS PENSADO EN ESTO?

Alma mía, si no conoces tu fin, ve un impulso y un signo en tu comienzo. Estás fundada en nada y construida en el vacío, Tu entrada asemeja a tu salida, tu vida asemeja a tu final.

Entonces, ¿por qué descansas y te alimentas de la vanidad?

Vuelve, te estás moviendo como tienda de nómada;

no te encontrarán cuando te busquen solicitado.

¿Cómo es que no te has pensado en esto?

Te has aferrado a tu deseo, que es realmente tu enemigo. 
You have not realized that your time is near. Her wine has deceived you, her bread has seduced you,

Until all your battle-friends are beginning to tire. Your armor-bearers now fight against you. The requital is here for the evil you do.

Put your wine back into the vault.

How is it you have not given this thought?

You have sought for too long what you will leave behind,

But you can pursue the goodness of God if you will.

What is the purpose that you have in your mind,

When you repent but once, and sin all your fill-

Once for your creator, many times for you alone.

How can your sin end when at your right hand Stands Satan ready for the assault?

How is it you have not given this thought?

Fate has played with you, driven you to sin, To build and possess; and still you want more. All this will vanish, and on what can you lean? Have you not taken delight for your reward?

You are a servant of the living God. Why Have you enslaved yourself to the earth? Repent and find

What you will say before your Lord's court.

How is it you have not given this thought?

Why have seduced me with nothing, $O$ world! I shall not respond any more, whether you give or take joys.

How can I rejoice on this earth or be sad?

I stay but a short time, whether Fate exalts or destroys,

Raises or deposes, gives peace or terrifies.

Whether I serve or be master, it is death that divides

All the links we have wrought.

How is it you have not given this thought?
No has notado que tu tiempo está cerca.

Su vino te ha engañado, su pan te ha seducido, todos tus compañeros de batalla han comenzado a fatigarse;

tus escuderos luchan ahora contra ti; el salario está aquí por la maldad que hiciste.

Devuelve tu vino de vuelta a tu bodega.

¿Cómo es que no te has pensado en esto?

Haz buscado mucho tiempo lo que dejarás atrảs,

pero tú puedes, si lo quieres, buscar la bondad de Dios.

¿Qué pretendes en tu mente

si te arrepientes una vez y luego pecas a todo poder?

Una vez por tu creador, muchas otras por ti solo.

¿Cómo puede tu pecado terminar si a tu derecha Satán está presto a asaltarte?

¿Cómo es que no te has pensado en esto?

El destino ha jugado contigo, guiándote a pecar, a construir y poseer, y tú deseas aún más.

Todo esto desaparecerá, y $\mathrm{Z}_{\mathrm{e}}$ qué te puedes apoyar? ¿No has considerado el placer como tu premio?

Eres siervo del Dios viviente. ¿Por qué te has esclavizado a la tierra?

Arrepiéntete y encuentra

lo que dirás ante el tribunal de tu Señor.

¿Cómo es que no te has pensado en esto?

¡Por quế me has seducido con nada, oh mundo! Yo responderé más, si me das o me quitas regocijos.

¿Cómo puedo gozar o entristecerme en esta tierra?

Estoy, pero por poco tiempo, sea que el destino me ensalce o me destruya, me eleve o me derribe, me dé paz o dé terrores.

Sea que yo sirva o señoree, es la muerte quien divide

todas las uniones hemos forjado.

¿Cómo es que no te has pensado en esto? 
Padre del hijo, arrastrado junto a su lamento, distanciado por Dios de ti:

Tu hijo, tu único hijo

El hijo que tú amas, Isaac.

Yo soy el hombre que ha visto la destrucción, del regocijo ido.

Alas, yo he perdido el fruto de mis espaldas, y nunca me lo pude imaginar;

Porque yo pensé que a mis años

él podría estar bien y sólido.

Pero yo he trabajado en vano,

Yo he engendrado un hijo, me he desalentado.

¿Cómo mi corazón puede estar agradado

con la partida de Isaac?

Yo he de lamentar y lagrimear cada minuto, y elevo un llanto lastimero,

cuando yo recuerdo, como hace tres años

Él murió en una tierra extranjera;

Como él viajó de lugar en lugar,

mi alma anhelante tras él,

hasta que yo lo traje de vuelta a mi casa.

mientras yo lloré noche y día.

¡Cuántos lamentos me ocurrieron!

¡Éstas son las generaciones de Isaac!

Mi amigo, toma mi abandono.

Si tú me consuelas, tú me lamentas.

No rememores mi alma querida, no me obligues a oír tu nombre.

El pequeño fuego que me fue dejado

el destino lo ha apagado. ¿Puede dañarme más?

Me ha abrumado con desastre eterno.

Se ha llevado el encanto de mis ojos.

Mi carne y mi corazón han llegado a su fin, junto con el fin de Isaac.

Dios, en cuyas manos está todo,

Quién deseará con todas tus criaturas,

hablar la pena del corazón de un padre.

Quién ha tenido tu nombre desde los dias de su juventud, despertar tu espiritu de consolidación por él,

y entrar en su alma dividida.

Él enseñó su amor para tenerte

para caminar en la senda de su antepasado.

Tú dictaste mientras él todavía estaba joven, el camino para tu sirviente Isaac. 


\section{INTRODUCCIÓN METODOLÓGICAY TEÓRICA PARA ENFRENTAR LOS TEXTOS POÉTICOS}

\section{REFLEXIONES PARAUNAMETODOLOGIADELECTURA}

Las primeras preguntas que nos vienen a la cabeza al momento de diseñar y justificar una metodología son: ¿qué es lo que debemos indagar en los poemas?, ¿qué clase de objetos son éstos?, ¿qué buscamos mostrar? y ¿a quién va dirigido el resultado de la investigación?

La primera respuesta despeja el camino.

Siempre trabajamos pensando en otro investigador, lo que, además, supone un conocimiento no ingenuo para enfrentar un texto y un arsenal de metalenguajes para profundizar su conocimiento. Pero esto supone una certeza que, a mi parecer, está lejos de ser absoluta; esto es, hablamos de un lector capaz de reproducir cabalmente una intuición semejante a la que lo creó y comprender la verdad que lo sustenta.

¿Es lo que debiéramos hacer con estos textos?, ¿aseverar lo que significan?

La verdad es que nunca me convenció esa metodología. Pienso y defino que este trabajo tiene su aporte centrado en el instante de rescatar textos escritos hace, al menos, nueve siglos; es un intento de sacarles el óxido de alrededor y dejar despejado el camino del tiempo para que, primero, cualquier lector pueda recobrar aunque sea una pequeña porción del sentir que les dio origen en la pluma de Abraham Ibn Ezra, y desde luego, que existan como documentos para el crítico que desee profundizar acerca de la literatura hispano-hebrea en los siglos XI y XII.

Esta preocupación por la recepción del lector se agudiza desde el momento en que descubrimos que fuera del ámbito intelectual o creativo en que nos relacionamos, la gente tiene aversión a la poesia y, lo que es peor, ese es un distanciamiento por incomprensión. Asunto que es reforzado cuando deciden leer algún libro que les dé señas para comprehenderlo y descubren que no saben por ejemplo, que selihá significa perdón, que hay metáforas culturales como la esposa que representa a lsrael y el esposo que representa a Dios. En definitiva, descubren un nivel desconocido que desemboca en una autodescalificación respecto de la propia sensibilidad poética.

Este es un problema que nos debiera preocupar y bastante, pues ¿quiénes son los responsables de este fenómeno, además de los procesos socio-culturales provocados por los medios de comunicación y por los valores superfluos y consumistas? Lamentablemente nosotros y los críticos.

Es papel del investigador en cuanto critico contribuir al desarrollo cultural de una sociedad. Jamás olvidaré, cuando en el primer año de literatura tuvimos un ramo que se llamaba "Ciencias Humanas", y descubrimos la función que éstas tenían dentro de la sociedad: guiar a una cultura en su desarrollo espiritual. 
Por ello, nuestra preocupación ha estado centrada en el lector común, en las lecturas posibles de realizar frente a una obra, una obra que además conlleva el problema del tiempo. Pero es el lector el que completa ese ciclo de reactualización de una obra; es él quien intenta reproducir el fenómeno interno del poema, pues cada lectura aporta su propio sistema cognitivo, capacidad interpretativa, acervo cultural y, por sobre todo, temple, que será provocado por las imágenes poéticas que tienen precisamente una significación poética, es decir, una evocación determinada por el contexto exterior, público, y otra evocación interna, movida por lo afectivo, lo intuitivo y las áreas de experiencias de vida que haya desarrollado el lector.

Con estos fines, el apoyo metodológico lo hemos tomado, entre varios otros autores, del español Dámaso Alonso, quien dedicó un libro completo, Poesía Española. Ensayo de métodos y limites estilísticos ${ }^{15}$, al estudio de Jos niveles de conocimiento de una obra poética según niveles distintos de lectura, que deben necesariamente responder a un orden establecido de continuidad.

El primer conocimiento de la obra poética es el del lector; el segundo conocimiento es función de la crítica (a condición de que no obvie ni olvide el primero, el de la lectura llana, ingenua y entusiasta) que debe ser guía para ayudar al lector-receptor a reproducir la intuición y temple que creó dicha obra; el tercer conocimiento de la obra poética pertenece al ámbito de la estilística y es la fase en que, según Dámaso Alonso, se podría llegar a obtener algunas consideraciones universales (leyes) respecto de la poesía.

Los tres niveles se sustentan en el reconocimiento de una forma interna y otra forma externa del poema, definida por la dirección de la relación entre significado y significante.

Si bien estos términos vienen de la herencia saussuriana, Dámaso les otorga otra relevancia. En términos generales, para Saussure el significado era el concepto y los significantes transmisores de éstos o imágenes acústicas. Pero no es tan simple, asevera Alonso. Un significante emana, evoca y moviliza innumerables vetas del entramado psíquico del oyente ( $\mathrm{y}$ también del hablante), y a través de ellas percibe éste la carga contenida en la imagen acústica. Significado es, entonces, esa carga compleja.

De ningún modo podemos considerar el significado en un sentido meramente conceptual. Diremos pues, que

un significado es siempre complejo y que, dentro de él se pueden distinguir una serie de significados parciales ${ }^{16}$.

Es así como hay elementos en los versos de un poema cuya comunicación nunca es inmediata: la rima es uno de ellos, las reiteraciones, los estribillos, etcétera. Hay versos, partes del poema, cuyo sentido solo se adquiere al pasar por otro verso, por otra parte de la obra, etcétera. 
Un análisis parecido del significante nos llevaría a considerarlo también como un complejo formado por una serie de significantes parciales.

Es en esta red conformada por significantes y significados en la que se mueve el poema, y en donde radica su posibilidad de reactualización en cualquier lectura, independiente del tiempo y del nivel de complejidad cognitiva del receptor. No hay que olvidar que siempre hay una vinculación emotiva entre significante y significado, y esa motivación es la que reactualiza cada lectura o lector.

Dámaso Alonso lo explica refiriendo que

un significado no es esencialmente un concepto, sino que el significado es una intuición que produce una modificación inmediata ${ }^{17}$;

un significante es todo lo que en el habla modifica leve o grandemente nuestra intuición del significado ${ }^{18}$.

Entonces, entenderemos por forma exterior la relación entre significante y significado, en la perspectiva que guía desde el primero hacia el segundo. Y la misma relación, pero en la perspectiva desde el significado hacia el significante, es lo que llamaremos forma interior.

Este trabajo está hecho desde la perspectiva de la forma exterior, desde la perspectiva del significante al significado, simplemente porque desde allí se produce la lectura llana o primera de una obra.

Lograr penetrar la forma interna es la función de la estilística que permite llegar a postular, quizás, verdades más generales y absolutas respecto al funcionamiento del texto poético.

Pero hay que señalar que, obviamente, esta división de forma interior y exterior es esencialmente didáctica, para poder intentar distinguir los efectos en una interpretación según el tipo de lectura. De manera más real, el poema es un tejido que a medida que penetramos y hacemos asible nos va revelando significados inesperados, nuevos e impensables muchas veces. Al fin y al cabo, el arte es una expresión libre.

Al igual que Dámaso Alonso y que Lisa Block de Behar, nosotros pensamos que las obras literarias no han sido escritas para lectores como los críticos, investigadores o comentaristas, sino que, aun teniendo fines formativos, educativos o de conservación de la tradición, como es el caso de la gran mayoría de estos poemas, han sido escritos para lectores sencillamente dispuestos a ser provocados por la "capacidad de asombro", interesados "por un algo" en leer, y ese "algo" significa que "esperan algo del poema" en el cual ellos serán cocreadores al momento de reproducirlo y reactualizarlo en el proceso de lectura. Y más aún: cada lectura que vayan haciendo ellos mismos será otra lectura nueva... pero nunca la que hizo Abraham Ibn Ezra de su obra. 
Si empiezo a tirar del ovillo iba a salir una hebra de lana, metros de lana, lanada, lanagnórisis, lana túrner, lanapura, lanatomía, lanata, lanatalidad, lanaturalidad, la lana hasta la náusea, pero nunca el ovillo (Julio Cortázar).

Pues bien, si la obra nació para ser intuida, y esa intuición es provocada y modificada por los significantes y significados aquí definidos, demos lugar al encuentro de ambas intuiciones (la del autor y la del lector).

La obra principia sólo en el momento en que suscita la intuición del lector, porque sólo entonces comienza a ser operante ${ }^{19}$.

El primer conocimiento de la obra poética es, pues, el del lector, y consiste en

una intuición totalizadora, que iluminada por la lectura, viene como a reproducir la intuición totalizadora que dio origen a la obra misma, es decir, la del autor. Este conocimiento que adquiere el lector de una obra literaria es inmediato, $y$ tanto más puro cuanto menos elementos extraños hayan interpuestos entre ambas intuiciones ${ }^{20}$.

Bajo estos conceptos, tanto el autor como el lector poseerán una intuición de tipo artístico. Ella se diferencia de la científica, en que el artista para la interpretación o recepción de una obra, moviliza, provoca o evoca la totalidad de la psiquis: la memoria, la fantasía, la voluntad y el entendimiento. En cambio, científicamente, intuimos con solo una veta de nuestra psique, pues la intuición científica no es afectiva ni deja libre la fantasía. Esto no lo debemos olvidar quienes deseamos dar cuenta de una obra. Y para ser claros y justos, ni la intuición cientifica ni la artística dan cuenta total de una obra por separado. Roland Barthes hace años que discute este tema respecto a la función que cumpliría la "Ciencia Literaria", sobre todo porque, al fin, tan solo el retorno a la experiencia del texto logra hacernos sentir que hemos comprehendido algo realmente propio del poema.

"Gracias a la operación poética, la materia reconquista su naturaleza: el color es más color, el sonido es plenamente sonido. En la creación poética no hay victoria sobre la materia o sobre los instrumentos, como quiere una vana estética de artesanos, sino un poner en libertad la materia" (Octavio Paz).

19 ldem, p. 38.

20 Id. Ibid. 


\title{
INTENTO DE UNAPRIMERAINTERPRETACIÓNDESDE UNALECTURALLANA
}

\author{
BAQQAŠA
}

El título nos involucra de inmediato con el temple de ánimo del poeta. Baqqaša denota exhortación a Dios, petición a Dios. Pero si quedase alguna duda o algún lector no supiese el significado concreto de este término, éste se le traducirá en un estado espiritual muy asible luego de leer el texto completo.

No hay tregua. El hablante abre el poema con un pleonasmo -repetición de una palabra o idea- explicitando la necesidad de reafirmar(se) la existencia y grandiosidad de Dios: En verdad, Dios verdadero Tú eres, aunque yo no te vea.

Hay un reforzamiento de la existencia del sujeto ficticio-Dios, al interior del poema-para reconocer al oyente al que se dirigirá el hablante. Claro que es un doble diálogo, uno con Dios, . que a su vez no sirve para el monólogo interior del hablante.

En los versos tres y cuatro se expresa la admiración de la permanencia fiel de Dios con sus bondades atemporales e incondicionales, y el recogimiento del hombre -figurado-frente a su irresponsabilidad con Dios: hasta el presente me has recordado mientras que yo jcuántas veces te he olvidado!

Aquí comienza a aparecer un tema central de la cultura judaica, el sentido de responsabilidad, que en los versos siguientes y finales se integra con el sentido del retorno o tešuva, del arrepentimiento.

Pero otra característica propia del judaísmo es el concepto del arrepentimiento sin la noción practicada en casi todo el Occidente y más, de pecado y castigo. Se trata de un retorno a Dios bajo un diálogo directo entre Dios y el hombre; él-el hablante-que se hace cargo de su sentido de responsabilidad y compromiso con Dios frente a sí mismo.

La exhortación o bagqaša tiene ese sentido. Es una advertencia con que se intenta persuadir a Dios metafóricamente, pues es una toma de conciencia del vínculo que desea retomar con Dios. De hecho, el hablante comparte la certeza de que Dios nunca ha sido quien lo ha dejado, ha sido el hombre quien se ha abandonado a sí mismo.

El doble diálogo del hombre consigo mismo y con Dios concluye en el último verso octavo- con la aprehensión y aceptación de los precepto o mitzvot, los cuales rigen la vida judia: Mis delicias están en tu ley sin que necesitaras recompensa; y en como Dios de mi vida te invoco...

La comunicación directa entre Dios y su pueblo está representada por el uso del vocablo de pronombre personal de género masculino o femenino y número singular Tú y de los pronombres posesivos tu, tus, presentes en cada par de versos. $\mathrm{Y}$ en el verso seis: muy excelso es tu nombre, pero próximo yo te he encontrado. 
El Dios no culpógeno ni castigador queda representado en el verso cinco: "Tu voluntad ha sido favorecerme sin que necesitaras recompensa". Esto, a su vez, otorga un temple calmo y tranquilo al hablante poético, pues sabe que Dios le cree su reconocimiento; núcleo en el que radica el valor y la perdurabilidad del sentido de la responsabilidad en la religión judía.

\section{SELIHA N ${ }^{\circ} 105$}

En la presente compilación hay tres poemas titulados como Selihá, término que significa perdón.

Los tres Selihot en su diversidad tienen un temple común de dolor, pena y lamento, que en términos literarios responde a lo que se conoce como 'elegía': poemas que expresan un sentimiento de dolor ante cualquier circunstancia penosa, como la muerte de un ser querido, la tristeza ante una ruinas, la añoranza del tiempo pasado, etcétera.

En este sentido, el temple del hablante lírico es el mismo para otro poema compilado, Qiná, que significa lamentación. La Qiná expresa precisamente el dolor por la ruina de las comunidades judias en España causada por los almohades. Ahora, la diferencia con Selihá, es que esta última pide perdón para restaurar la armonía, pide perdón porque la pena que sufre el hablante es provocada luego de la revelación: "Mi mala inclinación me haya descarriado, pues no era mi voluntad hacerte agravio" (vs.17).

En este sentido, la Selihá (todas ellas) tiene y cumple su objetivo absolutamente: evocar la situación angustiosa que conlleva el esperar el perdón, que a su vez lo realiza. Cada verso es una entidad suficiente para expresarlo. Es una cadena de versos enteros, que usan y abusan de la redundancia, la tautología y el pleonasmo. Todas figuras literarias que refuerzan el sentido o estado de ánimo del hablante: necesidad de ser perdonado y de perdonarse a sí mismo.

En definitiva, el hablante está inquieto buscando el perdón de Dios. Cuestiona, reflexiona, reitera e intensifica el conflicto, dando espacio a que la respuesta brote desde este espiral retórico consigo mismo, pero que supone la omnipresencia de Dios: "¿Cómo me congraciaré con él? ¿Con mi espiritu? ¿Acaso no viene de él?" (vs. 4).

Cuando en este proceso de reflexión didáctica el hablante comienza a aceptar lo que significa la excelsitud de Dios, le emerge metódicamente otra duda, la duda de la enseñanza y formación, objetivo que también buscan los poemas de tema religioso o sagrado. El hablante piensa: si Dios está aquí y en mí, ¿cómo mi lengua lo ilustraria?/inaccesible más que los altos cielos, y próximo más que mi carne y mis huesos/"(vs. 5 y 6 ).

Esta manera de introducir al receptor en el conflicto temático del poema, lo transforma directamente en un receptor activo, importantísima e ilustrativa forma del carácter formativo de algunos poemas hispano-hebreos de la época. Plantea al receptor o hablante real desde el hablante lírico la posibilidad de la duda frente al tema de la fe, como a su vez la necesidad y oportunidad de resolverla. 
Lo vital para el hablante y, por extensión, para el pueblo judio, es cómo cada uno, directamente, se acerca a Dios. ¿Cómo congraciarse con él? La respuesta es el perdón. Desde un principio el poeta nos quiso introducir en el asunto del cómo, luego de alejarse de Dios-el hombre, no Él- puede retornarse a él. De hecho, el título del poema que guía la lectura e interpretación del texto es Selihá, que significa perdón.

El camino se inicia por la expresión del conflicto de duda y, luego, por la conciencia de que sí, que Dios está en él y le entrega todos sus dones. Entonces, el discurso poético se torna menos tenso. En el verso nueve hay muestras de esta primera aceptación con una interrogante retórica: "¿Cómo esperaría salvación de parte de ella? Mentira es el auxilio de las criaturas/Ciertamente el siervo no puede refugiarse sino en el aquel que lo adquirió/",

Para el perdón debe haber, además, aceptación de culpa o de pecado -jet-, de responsabilidad en la gestación del conflicto: "¿Cómo levantaré mi mirada hasta ti? Si también ella ha pecado". Pero no es culpa en tanto castigo o penitencia, sino aceptación de irresponsabilidad y necesidad de retomar las enseñanzas absorbidas en el seno del núcleo familiar o comunitario judio. Retornar a las enseñanzas y al sentido de responsabilidad para con uno y con el pueblo al que pertenece.

Dolor y, entonces, demanda imperiosa a Aquél que posee los dones y que como tal es el único que ayuda a encontrar la respuesta: "Mis maldades a mi solo han afectado, pues Tu sólo me dispensas benignidades. Muéstrame el camino de mi salud pues todo lo que yo sé, Tú me lo has enseñado" (vs. 18-19).

El hablante ha realizado el camino del aprendizaje de la ética judaica respecto de Dios y de sí mismo, ha reflexionado su duda consigo mismo y no solo ante Dios, sino con Él. Pues entre el devoto y Dios solo existe un diálogo directo sin intermediarios, y es el individuo frente a sí mismo quien debe responder a las enseñanzas recibidas y enmendar el camino. El hablante sabe que él mismo las ha aprehendido.

Entonces, el temple del poema cambia, se alza una voz segura, directa, sin quejidos ni culpas, sino clara, asumida y responsable que solo pide ahora que Dios lo haya oído: "Las palabras de mi corazón hice sentir en mi oido. 'Óyelas tú, desde los cielos!" (vs. 20).

Sencillamente es la honestidad del ser humano consigo. De nada servirían promesas y castigos si no ha existido un compromiso responsable e intimo. Ese es el camino para retornar a Dios y merecer sus dones, el saber crecer en la responsabilidad. El hombre cuando peca contra Dios, no lo hace en realidad en su contra, sino contra si mismo.

Es de notar la importancia, una vez más, de las mitzvot o enseñanzas. Éstas me ponen en contacto con Dios y si las rompo quiebro mi propia integridad y es de esto que toma conciencia el hablante en el poema: reconocimiento del Poder Creador. 
Zulat es la oración de un siervo en nombre de sus fieles y pueblo. Esta oración es laudatoria de los dones de Dios y de los bienes que ya ha dado y de los que dará aún a su pueblo, Israel.

Es una oración al futuro venidero, a la llegada del Mesías y con él de los buenos tiempos, pasada ya las desventuras. Para ello, el poeta eligió la forma de diálogo, personificando las partes en cuestión. Es decir, Israel que le habla a Dios, le pide retomarles lo propio mientras lo celebran con oraciones, cánticos y cítaras. Le demandan con la certeza de todos los males que ya han soportado y del tiempo que han esperado la llegada del Mesías, el Profeta, y con la esperanza de que la redención no se hará esperar más.

Dios responde solo una vez, a su pueblo bajo el nombre de esposa y, también, le demanda "¡Oh esposa!, sal del cautiverio.." como gacela, a la tierra prometida-vuelve después que fuiste dispersada". Aquí hay un paralelismo expresivo con la forma bíblica del Cantar de los Cantares, que representa la mística en el vínculo que une a Dios con su esposa, Israel.

El poema expresa que el pueblo de Israel está bien en Dios, que está preparado y deseoso de recibirlo en sus bondades y que espera en conciencia de sus pesares y devoción, la respuesta a tan imperante demanda: (Israel) "Cobijo mio", dice a Dios, "el dolor de mi llaga alivia, y torne la salud/ aparta la violencia de mis opresores, da prosperidad a mis amadores, $/$ ya que varios plazos y aún medio plazo, la redención he esperador', y no lo exhorta, sino que le ordena perentoriamente que "a quien invoca tu nombre, responde; el rebaño que vendiste, rescata; el muro que demoliste, reedifica; la mansión que desechaste, habita, y acelera mi salvación/".

Esta forma dialogada es usada por Abraham Ibn Ezra en otros poemas también: Gueulá y Ahabá.

En Gueulá es Dios el que hace la introducción, utilizando un verdadero tono de himno. El himno es una composición solemne en que el hablante, en este caso personificado en el poeta, exalta temas grandiosos como Dios, un héroe o la Patria, donde para la ocasión, Israel, su pueblo, es el tema.

Dios dice: "Afligida mia! Hasta ahora estabas desolada,/pero levántate, sube, pues has sido perdonada.//Cuán bella eres, cuán agraciada!". $d a ! "$

Y esto es reforzado a través de la fómula de estribillos: "¡Cuán bella eres, cuán agracia-

En el $A$ habá, que significa Amor, expresa a través del diálogo personificado entre Dios e Israel el vínculo amoroso entre Dios y su pueblo. Pero se presenta un conflicto, se necesita interrogar para averiguar en qué se sustenta el amor de Dios hacia Israel, que ha sufrido. Israel le dice: "Descansan pacificos mis adversarios/mientras yo voy desterrada y errante". Pero Dios le responde con otra pregunta: "Interroga, oh ciudad de Ariel (Jerusalén), / interroga si es que te he olvidado, / ciertamente lágrimas a raudales vierten mis ojos,/ puesto que huérfana de gloria te he dejado". 
Israel, sin sentir una respuesta, más que retóricamente, le interpela más fuerte, declarándole su amor y que por su fidelidad amorosa no entiende estos pesares por los que deben pasar y están pasando; no entienden cuál es la razón de un amor expresado asi, si él, Dios, todo lo puede: "¿Cómo te habria yo abandonado?/ ¿Por gracia de tus dias juveniles con amores eternos te he amado!/ ¿Dónde está tu poder, oh diestra de Dios?”.

Importante es destacar que esta forma dialogada es propia del Antiguo Testamento o de la Biblia, que busca la comprehensión de los temas en cuestión: la fe, el amor, la duda, las obligaciones, las enseñanzas, el sentido de responsabilidades, la honestidad, etcétera.

Abraham ibn Ezra, como ya se dijo, nos legó poesía profana y poesía sagrada. Los comentarios que acabamos de hacer corresponden a poesía sagrada, donde destacan los dotes líricos del poeta y, sobre todo, su fervor y dedicación a los asuntos bíblicos que, como sabemos, estudió profusamente.

Lo sagrado responde en términos generales y según la Real Academia de la Lengua, a poemas cuyo contenido refiere a temáticas dedicadas a Dios y al culto divino. Para desarrollar estos temas utilizo poesías himnicas, donde canta a la gloria de Dios, su inaccesibilidad, su reino sobre todos los seres, desde los coros de los ángeles, esferas celestes y planetas que discurren en sus órbitas.

También expresa la materia sagrada a través de poesías laudatorias, penitenciales, suplicatorias o de exhortación, elegías como la qiná, las de tipo epitalámico del Cantar de los Cantares como la Gueulot y la Ahabot. Asimismo, en particular, señalamos que las ginot y zulot se presentan en forma dialogada. En todas ellas, la esperanza mesiánica, la tradición nacional judaica, es cantada en forma muy bella y consoladora.

Todos los estilos y poemas arriba nombrados se distinguirán de los poemas profanos, en que éstos no sirven para usos sagrados, sino que para usos puramente seculares, entendiendo por secular lo no sagrado o consagrado.

Definidas las diferencias, el poema siguiente (el 176) en sus tres versiones y, también el numerado 175 del registro, parecerían, sobre todo por su comparativa libertad de composición y de expresión, ser poemas profanos, pero notaremos que expresan un canto a la naturaleza y la armonía del cosmos (175) y un fuerte reconocimiento del mundo creado por Dios.

Pero particularmente el 176 representa un tema secular: la fatalidad inevitable, tópico medieval bastante reiterado, tales como el tópico de la rueda de la fortuna o el de la muerte inevitable.

Otro peculiar asunto que nos plantea este poema es el de la traducción o el de las fuentes. Como podemos observar, las tres versiones son distintas y en términos absolutos y severos metodológicamente nos podría llevar a tres interpretaciones distintas, más bien a tres poemas diversos: 
La esfera y los signos zodiacales se desviaron

en sus órbitas, al momento de mi natividad;

si la mercancia objeto de mi comercio fueran lámparas,

el sol no se habría ocultado hasta el momento de mi muerte;

aunque me esfuerzo por prosperar, no tengo éxito alguno,

pues pervierten mi suerte las estrellas de mi cielo;

si fuera mercader de sábanas,

no moriria nadie durante mis dias.

\section{LUCKLESS}

The planets and spheres in their stations

Changed their order when I first drew breath.

If i were to be a seller of lamps,

The sun would not set till after my death!

The stars in my heaven have ruined my life.

I cannot succeed however I strive.

If I were to be a seller of shrouds,

No one would die while I was alive!

\section{SIN SUERTE}

Los planetas y esferas en sus estaciones cambiaron su orden cuando di mi primer respiro.

Si es que yo fuera un vendedor de luces,

El sol no se pondria antes de mi muerte

Las estrellas en mi paraíso han arruinado mi vida.

No puedo triunfar a pesar de que lucho.

Si es que yo fuera un vendedor de mantas,

nadie moriría mientras yo estuviera vivo!

Claro que a su vez recalca otro asunto que se planteó en la metodología: las posibilidades de recrear la intuición del autor en la lectura llana, es decir, poder reconstruir en términos intuitivos, como lo usa Dámaso Alonso, el temple esencial que movió la gestación del poema, el motivo que lo sostiene, pues a pesar de las diversas versiones, las tres evocan los mismos significados, que concluyen en un sentido de fatalidad, en donde el temple del poeta es inevitablemente reconocible. 